\title{
Mini-Review
}

\section{Prospective Treatment of Age-Related Diseases by Slowing Down Aging}

\author{
Mikhail V. Blagosklonny \\ From the Department of Cell Stress Biology, Roswell Park Cancer \\ Institute, Buffalo, New York
}

\begin{abstract}
Atherosclerosis, hypertension, obesity, diabetic complications, cancer, benign prostate hyperplasia, Alzheimer and Parkinson diseases, age-related macular degeneration, osteoarthritis, osteoporosis, and seborrheic keratosis are strongly associated with aging, implying a common underlying process. Each disease is treated separately and, in most cases, symptomatically. Suppression of aging itself should delay or treat all age-related diseases, thus increasing healthy life span and maximal longevity. But, is it possible to slow down aging? Recent evidence indicates that the target of rapamycin signaling pathway is involved in cellular senescence and organismal aging. Preclinical and clinical studies demonstrated the therapeutic effects of rapamycin in diverse age-related diseases. One simple reason why a single drug is indicated for so many age-related diseases is that it inhibits the aging process. (Am J Patbol 2012, 181:1142-1146; bttp://dx. doi.org/10.1016/j.ajpath.2012.06.024)
\end{abstract}

Humans and other mammals often die from age-related diseases, such as cancer, ischemic heart disease, hypertension, stroke, and complications of osteoporosis, type 2 diabetes mellitus, and Alzheimer and Parkinson diseases. Each disease is treated separately, for example, diabetes is commonly treated with insulin. However, insulin does not treat cancer; instead, it stimulates cancer. ${ }^{1}$ Furthermore, insulin promotes obesity and atherosclerosis, ${ }^{1}$ and insulin therapy likely worsens retinopathy. ${ }^{2}$ In addition, insulin-activated pathways promote aging. ${ }^{3,4}$ Therefore, while compensating for insulin insufficiency and insulin resistance in diabetes, insulin therapy may accelerate aging. Similarly, while treating cancer, radiation does not treat diabetes and other age-related diseases, if cancer were to be cured, other diseases would continue to limit life span. To prevent age-related diseases and, therefore, to extend healthy and maximal life span, it is necessary to slow down the aging process.

\section{mTOR and Geroconversion}

Mammalian target of rapamycin (mTOR) is a cytoplasmic kinase that regulates cell growth and metabolism. ${ }^{5}$ The mTOR pathway is activated by mitogens (eg, insulin-like growth factor- 1 and insulin) and nutrients (amino acids, glucose, and fatty acids), hormones, and oncogenic proteins (eg, Ras, Raf, MEK, phosphatidylinositol 3-kinase, and Akt; Figure 1). The mTOR pathway stimulates cell growth (causing cell hypertrophy), ribosome biogenesis, and protein synthesis (including aggregation-prone proteins) and inhibits digestion of defective mitochondria and aggregation-prone proteins. ${ }^{5}$ In proliferating cells, active mTOR stimulates cellular mass growth and metabolism. When the cell cycle is arrested, still active mTOR causes hypertrophy and, eventually, cellular senescence, ${ }^{6-8}$ characterized by large-cell morphological features and irreversible loss of proliferative/regenerative potential. The process of conversion of reversible arrest into senescence is termed geroconversion. ${ }^{9}$ Rapamycin and other inhibitors of the mTOR pathway decelerate geroconversion in cell culture. ${ }^{7,10,11}$ Rapamycin also prevents hyperactivation and exhaustion of stem cells in the organism, ${ }^{12,13}$ and it reverses cellular phenotypes and enhances mutant protein clearance in Hutchinson-Gilford progeria syndrome cells. ${ }^{14}$

\section{From Gerogenic Cells to Diseases using Atherosclerosis as an Example}

In arrested cells, mTOR increases cell size, differentiation, and differentiation-related cellular functions. Therefore, senescent/gerogenic cells with active mTOR are

\footnotetext{
Accepted for publication June 14, 2012.

Disclosure: M.V.B. is a consultant for Tartis-aging, which develops anti-aging drugs.

A guest editor acted as editor-in-chief for this manuscript. No person at Thomas Jefferson University or Albert Einstein College of Medicine was involved in the final disposition for this article.

Address reprint requests to Mikhail V. Blagosklonny, M.D., Ph.D., Department of Cell Stress Biology, Roswell Park Cancer Institute, Elm and Carlton streets, Buffalo, NY 14263. E-mail: blagosklonny@oncotarget.com or mikhail.blagosklonny@roswellpark.org.
} 


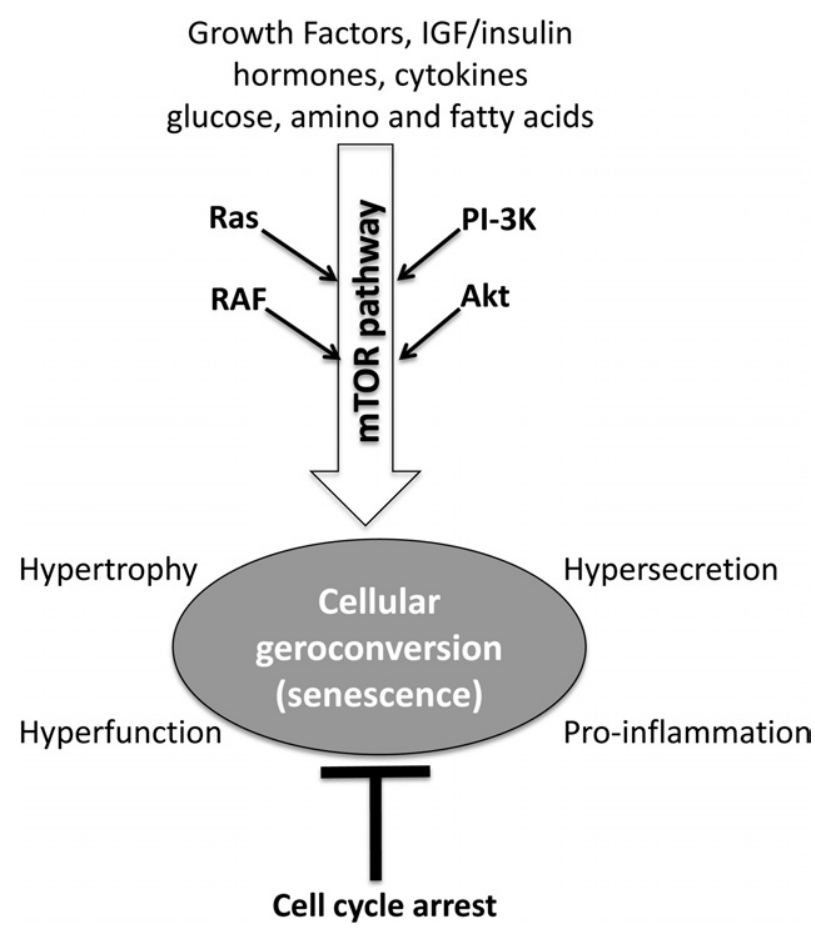

Figure 1. mTOR-dependent conversion from cell cycle arrest to senescence. When the cell cycle is blocked, active growth-promoting pathways, such as mTOR, cause cellular senescence (geroconversion). Cellular senescence is an irreversible state characterized by cellular hypertrophy, hyperactivity or hyperfunction, hypersecretory and pro-inflammatory phenotype, an inappropriate drive into S-phase associated with loss of regenerative potential, and resistance to signals (eg, insulin). Rapamycin decelerates or suppresses geroconversion. IGF, insulin-like growth factor; PI-3K, phosphatidylinositol 3-kinase.

hypertrophic and hyperfunctional or hyperactive. ${ }^{9}$ Functions of differentiated cells are tissue type specific. For example, fibroblasts, adipocytes, and immune cells secrete cytokines. Therefore, hyperfunctional fibroblasts, adipocytes, and immune cells cause pro-inflammation and fibrosis. Moreover, mTOR is involved in the hypersecretory phenotype of senescent cells. ${ }^{15}$ As another example, hyperfunctional osteoclasts resorb the bone, thus potentially causing osteoporosis. Liver cells produce lipoproteins, contributing to accumulation of lipids in the arterial wall; and platelets aggregate, leading to thrombosis. For example, atherosclerosis depends on hyperfunctions of local cells [endothelial cells, smooth muscle cells (SMCs), and macrophages] and distant cells (hepatocytes, bone marrow cells, and adipocytes). Atherosclerosis is associated with hypertrophy of arterial SMCs and activation of macrophages in the arterial wall. ${ }^{16,17}$ The development of atherosclerotic plaque involves endothelial activation, hypertrophy and hyperplasia of SMCs, monocyte migration, macrophage activation, uptake of lipids by activated cells, accumulation of fat, and formation of foam cells (Figure 2). Rapamycin inhibits monocyte/macrophage migration and their accumulation in carotid lesions of cholesterol-fed rabbits. ${ }^{18}$ Hyperfunctional adipocytes and hepatocytes increase levels of lipoproteins, such as low-density lipoprotein and procoagulation and pro-inflammation factors. Hyperfunction of bone marrow-derived cells, such as monocytes, lymphocytes, and platelets, contributes to atherosclerosis and thrombosis. Increased propensities to thrombosis, hyperlipidemia, pro-inflammation, and high blood pressure, which are systemic manifestations of cellular hyperfunctions, all contribute to atherosclerosis. In animal models, rapamycin slows the progression of atherosclerosis in apolipoprotein E-deficient mice that have elevated levels of cholesterol. ${ }^{19,20}$ Rapamycin (sirolimus) in heart transplant recipients prevents coronary artery disease. ${ }^{21}$ In patients with coronary atherosclerosis, oral rapamycin prevents restenosis after implantation of a metal stent. ${ }^{22}$

\section{Cancer}

Despite the common misconception that rapamycin may cause cancer, it has been known for a decade that rapamycin prevents cancers in renal transplant recipients. ${ }^{23-25}$ At 2 years after renal transplantation, patients receiving rapamycin (sirolimus) as a base therapy do not develop any malignancies. ${ }^{23}$ In addition, rapamycin prevented tumors and cured pre-existing tumors. ${ }^{26}$ For example, kidney transplant recipients who had biopsyproved Kaposi's sarcoma were switched to rapamycin therapy. Three months after the initiation of rapamycin therapy, all cutaneous Kaposi's sarcoma lesions had disappeared in all 15 patients. ${ }^{26}$ Rapamycin is also extremely effective in the prevention of cancer in animal models. ${ }^{27}$ The cancer preventive effects of rapamycin may be the result of its anti-aging effect. ${ }^{28}$ In fact, calorie restriction $(\mathrm{CR})$ that decelerates aging delays cancer. $\mathrm{CR}$ may slow aging by inhibiting mTOR. ${ }^{29}$

\section{Rapamycin for Diverse Diseases}

Preclinical studies in animals and retrospective clinical studies in humans suggest that rapamycin has the potential to prevent or treat osteoporosis ${ }^{30}$; obesity ${ }^{31,32}$; neurodegenerative diseases, including Alzheimer, Parkinson, and Huntington diseases and spinocerebellar ataxia $^{33}$; osteoarthritis ${ }^{34}$; liver, renal, cardiac fibrosis, and organ hypertrophy ${ }^{35-37}$; and age-related macular degeneration and diabetic retinopathy. ${ }^{38}$ Also, lifelong rapamycin administration ameliorates age-dependent learning and memory deficits in old mice. ${ }^{39}$ Increased activation of the mTOR pathway in liver and skeletal muscle of obese rats is involved in obesity-linked insulin resistance. ${ }^{40}$ The simplest explanation for the effectiveness of rapamycin in the prevention of so many age-related diseases is the fact that it decelerates a common underlying cause: aging or, on cellular levels, cellular geroconversion.

\section{Inhibition of mTOR Extends Life Span}

In fact, inhibition of the TOR pathway extends life span in yeast, flies, and mice. ${ }^{41-49}$ For example, when fed late in life (at the age of 600 days), rapamycin increased life expectancy by $38 \%$ in genetically heterogeneous female mice. ${ }^{43}$ In another study, rapamycin was administered to mice from the age of 9 months and produced significant increases in life span, including maximum life span. ${ }^{47}$ 


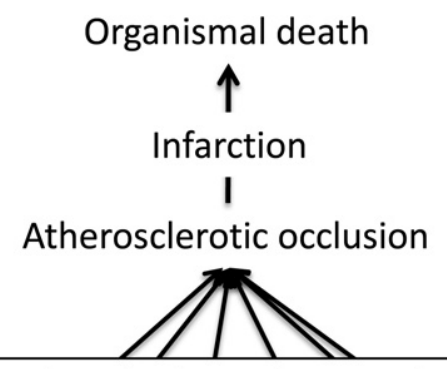

hypersecretion, proinflammation, hyperlipidemia, hyperinsulinemia, hyperaggregation, hypertension

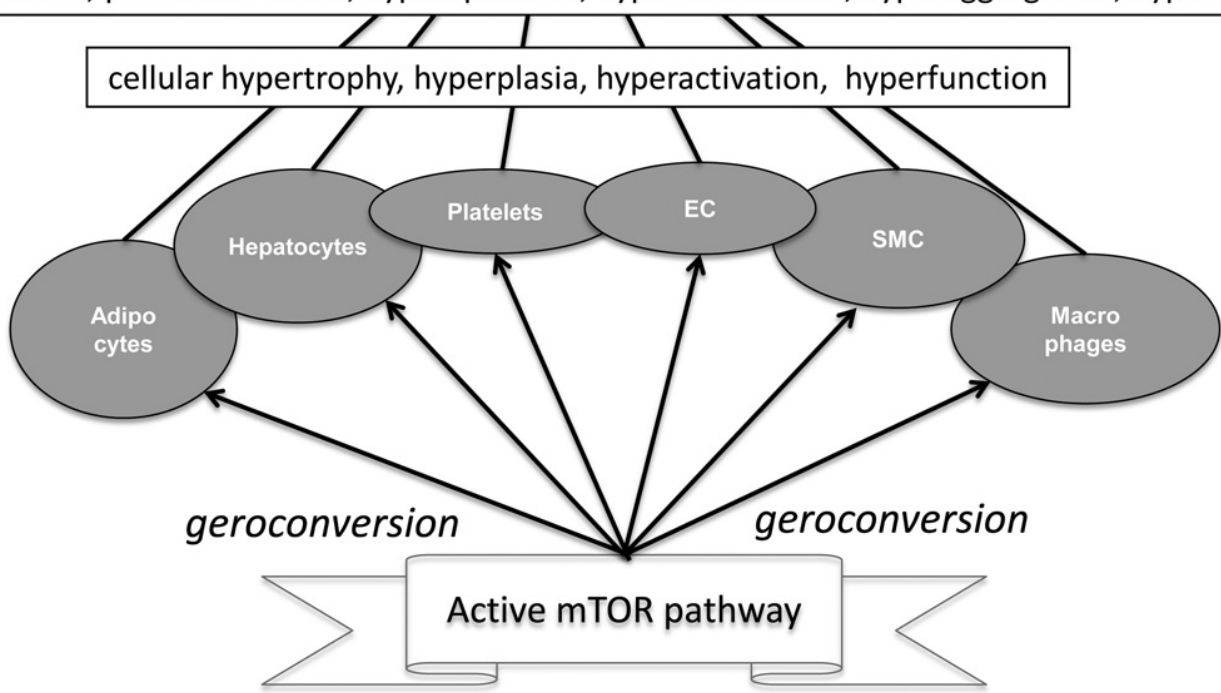

Figure 2. From geroconversion to organismal death (eg, atherosclerosis). Overactivated and hyperfunctional adipocytes, hepatocytes, monocytes/macrophages, megakaryocytes/platelets, endothelial cells (ECs), and SMCs altogether cause atherosclerosis. Atherosclerosis, in turn, leads to organ damage, such as myocardial infarction, leading to organismal death.

The median survival was extended by an average of $10 \%$ in males and $18 \%$ in females. The causes of death were similar in control and rapamycin-treated mice, consistent with a scenario that rapamycin delayed death from all causes. ${ }^{47}$ In inbred female mice, rapamycin (administrated intermittently: six times per month) increased life span (especially in the last survivors) and delayed spontaneous cancer. ${ }^{49}$ More important, intermittent (acute) treatment with rapamycin in mice does not inhibit mTOR complex 2, otherwise indirectly inhibited by high longterm doses of rapamycin. ${ }^{50}$ Yet, even starvation-like metabolic alterations, caused by high long-term doses of rapamycin, are not necessarily harmful. ${ }^{38}$

\section{Calorie Restriction}

There is a remarkable example that diseases can be delayed by slowing down aging. CR extends life span in a variety of species, including primates, rats, mice, fish, flies, and worms. ${ }^{51} \mathrm{CR}$ slows down organismal aging and, thus, delays age-related diseases. ${ }^{52}$ CR delays the onset of age-associated pathological conditions in primates. Specifically, CR reduces the incidence of diabetes, cancer, cardiovascular disease, and brain atrophy. ${ }^{53}$ Furthermore, CR slows aging and delays age-related diseases in nonobese humans. ${ }^{52,54,55}$ Some impressive examples include memory improvement in elderly humans ${ }^{56}$ and the attenuation of sarcopenia in rhesus monkeys ${ }^{53}$ and rodents by $\mathrm{CR}^{57,58}$ In humans, obesity accelerates sarcopenia, whereas weight loss slows sarcopenia. ${ }^{59}$ Furthermore, visceral adipose tissue modulates mammalian longevity. ${ }^{60}$ In humans, visceral fat accumulation is strongly associated with diabetes, atherosclerosis, thrombosis, hypertension, and other age-related diseases. Reduction of body weight decreases the risk of type 2 diabetes, hypertension, coronary heart disease, cancer, and dementia. Nutrients (food) directly and indirectly (via insulin secretion) activate the mTOR pathway. ${ }^{61,62}$ It was recently reviewed that CR may slow aging by inhibiting the mTOR pathway. ${ }^{29}$ Finally, dietary (calorie) restriction reduces cell senescence in mice, ${ }^{63}$ consistent with suppression of senescence by rapamycin in cell culture. ${ }^{7,11}$

\section{When Is It Too Late to Use Anti-Aging Drugs?}

Age-related diseases culminate in acute catastrophes, leading to disability and death. For example, atherosclerosis can lead to sudden death because of ventricular fibrillation or myocardial infarction and stroke (Figure 2). When these catastrophes occur, the process becomes a medical emergency and drugs that slow down aging will be useless. However, anti-aging drugs may prevent new catastrophes (eg, new infarctions). Osteoporosis coupled with sarcopenia and neurodegenerative conditions 
may ensure a broken hip after an elderly person falls. Anti-aging therapy will be of little or no use in emergencies, such as ventricular fibrillation and a broken hip. But, it will be useful to prevent and decrease atherosclerosis, osteoporosis, and neurodegeneration, which eventually lead to either a myocardial infarction or a broken hip. Anti-aging therapy will be most useful to prevent diseases or stop their progression, rather than to treat shortterm complications.

\section{References}

1. Berstein LM: Metformin, insulin, breast cancer and more. Future Oncol 2009, 5:309-312

2. Henricsson M, Janzon L, Groop L: Progression of retinopathy after change of treatment from oral antihyperglycemic agents to insulin in patients with NIDDM. Diabetes Care 1995, 18:1571-1576

3. Bartke A: Insulin and aging. Cell Cycle 2008, 7:3338-3343

4. Barzilai N, Huffman DM, Muzumdar $\mathrm{RH}$, Bartke A: The critical role of metabolic pathways in aging. Diabetes 2012, 61:1315-1322

5. Wullschleger S, Loewith R, Hall MN: TOR signaling in growth and metabolism. Cell 2006, 124:471-484

6. Demidenko ZN, Blagosklonny MV: Growth stimulation leads to cellular senescence when the cell cycle is blocked. Cell Cycle 2008, 7:33553361

7. Demidenko ZN, Zubova SG, Bukreeva El, Pospelov VA, Pospelova TV, Blagosklonny MV: Rapamycin decelerates cellular senescence. Cell Cycle 2009, 8:1888-1895

8. Leontieva OV, Blagosklonny MV: DNA damaging agents and p53 do not cause senescence in quiescent cells, while consecutive re-activation of mTOR is associated with conversion to senescence. Aging (Albany NY) 2010, 2:924-935

9. Blagosklonny MV: Cell cycle arrest is not yet senescence, which is not just cell cycle arrest: terminology for TOR-driven aging. Aging (Albany NY) 2012, 4:159-165

10. Demidenko ZN, Korotchkina LG, Gudkov AV, Blagosklonny MV: Paradoxical suppression of cellular senescence by p53. Proc Natl Acad Sci U S A 2010, 107:9660-9664

11. Leontieva O, Gudkov A, Blagosklonny M: Weak p53 permits senescence during cell cycle arrest. Cell Cycle 2010, 9:4323-4327

12. Gan B, Sahin E, Jiang S, Sanchez-Aguilera A, Scott KL, Chin L, Williams DA, Kwiatkowski DJ, DePinho RA: mTORC1-dependent and -independent regulation of stem cell renewal, differentiation, and mobilization. Proc Natl Acad Sci U S A 2008, 105:19384-19389

13. Chen $C$, Liu $Y$, Zheng $P$ : mTOR regulation and therapeutic rejuvenation of aging hematopoietic stem cells. Sci Signal 2009, 2:ra75

14. Cao K, Graziotto JJ, Blair CD, Mazzulli JR, Erdos MR, Krainc D, Collins FS: Rapamycin reverses cellular phenotypes and enhances mutant protein clearance in Hutchinson-Gilford progeria syndrome cells. Sci Transl Med 2011, 3:89ra58

15. Narita M, Young AR, Arakawa S, Samarajiwa SA, Nakashima T, Yoshida S, Hong S, Berry LS, Reichelt S, Ferreira M, Tavare S, Inoki K, Shimizu S: Spatial coupling of mTOR and autophagy augments secretory phenotypes. Science 2011, 332:966-970

16. Orlandi A, Bochaton-Piallat ML, Gabbiani G, Spagnoli LG: Aging, smooth muscle cells and vascular pathobiology: implications for atherosclerosis. Atherosclerosis 2006, 188:221-230

17. Siegel-Axel D, Daub K, Seizer P, Lindemann S, Gawaz M: Platelet lipoprotein interplay: trigger of foam cell formation and driver of atherosclerosis. Cardiovasc Res 2008, 78:8-17

18. Baetta R, Granata A, Canavesi M, Ferri N, Arnaboldi L, Bellosta S, Pfister P, Corsini A: Everolimus inhibits monocyte/macrophage migration in vitro and their accumulation in carotid lesions of cholesterol-fed rabbits. J Pharmacol Exp Ther 2009, 328:419-425

19. Pakala R, Stabile E, Jang GJ, Clavijo L, Waksman R: Rapamycin attenuates atherosclerotic plaque progression in apolipoprotein $\mathrm{E}$ knockout mice: inhibitory effect on monocyte chemotaxis. J Cardiovasc Pharmacol 2005, 46:481-486

20. Mueller MA, Beutner F, Teupser D, Ceglarek U, Thiery J: Prevention of atherosclerosis by the mTOR inhibitor everolimus in LDLR-/- mice despite severe hypercholesterolemia. Atherosclerosis 2008, 198:39-48
21. Keogh A, Richardson M, Ruygrok P, Spratt P, Galbraith A, O'Driscoll G, Macdonald P, Esmore D, Muller D, Faddy S: Sirolimus in de novo heart transplant recipients reduces acute rejection and prevents coronary artery disease at 2 years: a randomized clinical trial. Circulation 2004, 110:2694-2700

22. Rodriguez AE, Granada JF, Rodriguez-Alemparte M, Vigo CF, Delgado J, Fernandez-Pereira C, Pocovi A, Rodriguez-Granillo AM, Schulz D, Raizner AE, Palacios I, O'Neill W, Kaluza GL, Stone G; ORAR II Investigators: Oral rapamycin after coronary bare-metal stent implantation to prevent restenosis: the Prospective, Randomized Oral Rapamycin in Argentina (ORAR II) Study. J Am Coll Cardiol 2006, 47:1522-1529

23. Mathew $T$, Kreis $H$, Friend $P$ : Two-year incidence of malignancy in sirolimus-treated renal transplant recipients: results from five multicenter studies. Clin Transplant 2004, 18:446-449

24. Kauffman HM, Cherikh WS, Cheng Y, Hanto DW, Kahan BD: Maintenance immunosuppression with target-of-rapamycin inhibitors is associated with a reduced incidence of de novo malignancies. Transplantation 2005, 80:883-889

25. Campistol JM, Eris J, Oberbauer R, Friend P, Hutchison B, Morales JM, Claesson K, Stallone G, Russ G, Rostaing L, Kreis H, Burke JT, Brault Y, Scarola JA, Neylan JF: Sirolimus therapy after early cyclosporine withdrawal reduces the risk for cancer in adult renal transplantation. J Am Soc Nephrol 2006, 17:581-589

26. Stallone G, Schena A, Infante B, Di Paolo S, Loverre A, Maggio G, Ranieri E, Gesualdo L, Schena FP, Grandaliano G: Sirolimus for Kaposi's sarcoma in renal-transplant recipients. N Engl J Med 2005, 352:1317-1323

27. Granville CA, Warfel N, Tsurutani J, Hollander MC, Robertson M, Fox SD, Veenstra TD, Issaq HJ, Linnoila RI, Dennis PA: Identification of a highly effective rapamycin schedule that markedly reduces the size, multiplicity, and phenotypic progression of tobacco carcinogen-induced murine lung tumors. Clin Cancer Res 2007, 13:2281-2289

28. Blagosklonny MV: Prevention of cancer by inhibiting aging. Cancer Biol Ther 2008, 7:1520-1524

29. Blagosklonny MV: Calorie restriction: decelerating mTOR-driven aging from cells to organisms (including humans). Cell Cycle 2010, 9:683-688

30. Kneissel M, Luong-Nguyen NH, Baptist M, Cortesi R, ZumsteinMecker S, Kossida S, O'Reilly T, Lane H, Susa M: Everolimus suppresses cancellous bone loss, bone resorption, and cathepsin K expression by osteoclasts. Bone 2004, 35:1144-1156

31. Rovira J, Marcelo Arellano E, Burke JT, Brault Y, Moya-Rull D, BañónManeus E, Ramírez-Bajo MJ, Gutiérrez-Dalmau A, Revuelta I, Quintana LF, Campistol JM, Diekmann F: Effect of mTOR inhibitor on body weight: from an experimental rat model to human transplant patients. Transpl Int 2008, 21:992-998

32. Chang GR, Chiu YS, Wu YY, Chen WY, Liao JW, Chao TH, Mao FC: Rapamycin protects against high fat diet-induced obesity in C57BL/6J mice. J Pharmacol Sci 2009, 109:496-503

33. Bove J, Martinez-Vicente M, Vila M: Fighting neurodegeneration with rapamycin: mechanistic insights. Nat Rev Neurosci 2011, 12:437-452

34. Carames B, Hasegawa A, Taniguchi N, Miyaki S, Blanco FJ, Lotz M: Autophagy activation by rapamycin reduces severity of experimental osteoarthritis. Ann Rheum Dis 2012, 71:575-581

35. Neef M, Ledermann M, Saegesser H, Schneider V, Reichen J: Lowdose oral rapamycin treatment reduces fibrogenesis, improves liver function, and prolongs survival in rats with established liver cirrhosis. J Hepatol 2006, 45:786-796

36. Gao XM, Wong G, Wang B, Kiriazis H, Moore XL, Su YD, Dart A, Du $\mathrm{XJ}$ : Inhibition of mTOR reduces chronic pressure-overload cardiac hypertrophy and fibrosis. J Hypertens 2006, 24:1663-1670

37. Blagosklonny MV: Aging and immortality: quasi-programmed senescence and its pharmacologic inhibition. Cell Cycle 2006, 5:20872102

38. Blagosklonny MV: Rapamycin-induced glucose intolerance: hunger or starvation diabetes. Cell Cycle 2011, 10:4217-4224

39. Majumder S, Caccamo A, Medina DX, Benavides AD, Javors MA Kraig E, Strong R, Richardson A, Oddo S: Lifelong rapamycin administration ameliorates age-dependent cognitive deficits by reducing IL1 beta and enhancing NMDA signaling. Aging Cell 2012, 11:326-335

40. Khamzina L, Veilleux A, Bergeron S, Marette A: Increased activation of the mammalian target of rapamycin pathway in liver and skeletal 
muscle of obese rats: possible involvement in obesity-linked insulin resistance. Endocrinology 2005, 146:1473-1481

41. Stipp D: A new path to longevity. Sci Am 2012, 306:32-39

42. Kapahi P, Zid BM, Harper T, Koslover D, Sapin V, Benzer S: Regulation of lifespan in Drosophila by modulation of genes in the TOR signaling pathway. Curr Biol 2004, 14:885-890

43. Harrison DE, Strong R, Sharp ZD, Nelson JF, Astle CM, Flurkey K, Nadon NL, Wilkinson JE, Frenkel K, Carter CS, Pahor M, Javors MA, Fernandezr E, Miller RA: Rapamycin fed late in life extends lifespan in genetically heterogenous mice. Nature 2009, 460:392-396

44. Selman C, Tullet JM, Wieser D, Irvine E, Lingard SJ, Choudhury AI, Claret M, Al-Qassab H, Carmignac D, Ramadani F, Woods A, Robinson IC, Schuster E, Batterham RL, Kozma SC, Thomas G, Carling D, Okkenhaug K, Thornton JM, Partridge L, Gems D, Withers DJ: Ribosomal protein S6 kinase 1 signaling regulates mammalian life span. Science 2009, 326:140-144

45. Moskalev AA, Shaposhnikov MV: Pharmacological inhibition of phosphoinositide 3 and TOR kinases improves survival of Drosophila melanogaster. Rejuvenation Res 2010, 13:246-247

46. Bjedov I, Toivonen JM, Kerr F, Slack C, Jacobson J, Foley A, Partridge L: Mechanisms of life span extension by rapamycin in the fruit fly Drosophila melanogaster. Cell Metab 2010, 11:35-46

47. Miller RA, Harrison DE, Astle CM, Baur JA, Boyd AR, DE Cabo R, Fernandez E, Flurkey K, Javors MA, Nelson JF, Orihuela CJ, Pletcher S, Sharp ZD, Sinclair D, Starnes JW, Wilkinson JE, Nadon NL, Strong R: Rapamycin, but not resveratrol or simvastatin, extends life span of genetically heterogeneous mice. J Gerontol A Biol Sci Med Sci 2011 66:191-201

48. Anisimov VN, Zabezhinski MA, Popovich IG, Piskunova TS, Semenchenko AV, Tyndyk ML, Yurova MN, Antoch MP, Blagosklonny MV: Rapamycin extends maximal lifespan in cancer-prone mice. Am J Pathol 2010, 176:2092-2097

49. Anisimov VN, Zabezhinski MA, Popovich IG, Piskunova TS, Semenchenko AV, Tyndyk ML, Yurova MN, Rosenfeld SV, Blagosklonny MV: Rapamycin increases lifespan and inhibits spontaneous tumorigenesis in inbred female mice. Cell Cycle 2011, 10:4230-4236

50. Lamming DW, Ye L, Katajisto P, Goncalves MD, Saitoh M, Stevens DM, Davis JG, Salmon AB, Richardson A, Ahima RS, Guertin DA, Sabatini DM, Baur JA: Rapamycin-induced insulin resistance is mediated by mTORC2 loss and uncoupled from longevity. Science 2012, 335:1638-1643
51. Fontana L, Partridge L, Longo VD: Extending healthy life span: from yeast to humans. Science 2010, 328:321-326

52. Holloszy JO, Fontana L: Caloric restriction in humans. Exp Gerontol 2007, 42:709-712

53. Colman RJ, Anderson RM, Johnson SC, Kastman EK, Kosmatka KJ, Beasley TM, Allison DB, Cruzen C, Simmons HA, Kemnitz JW, Weindruch $\mathrm{R}$ : Caloric restriction delays disease onset and mortality in rhesus monkeys. Science 2009, 325:201-204

54. Fontana L, Meyer TE, Klein S, Holloszy JO: Long-term calorie restriction is highly effective in reducing the risk for atherosclerosis in humans. Proc Natl Acad Sci U S A 2004, 101:6659-6663

55. Soare A, Cangemi R, Omodei D, Holloszy JO, Fontana L: Long-term calorie restriction, but not endurance exercise, lowers core body temperature in humans. Aging (Albany NY) 2010, 3:374-379

56. Witte AV, Fobker M, Gellner R, Knecht S, Floel A: Caloric restriction improves memory in elderly humans. Proc Natl Acad Sci U S A 2009 , 106:1255-1260

57. Williamson DL: Normalizing a hyperactive mTOR initiates muscle growth during obesity. Aging (Albany NY) 2011, 3:83-84

58. Marzetti E, Lees HA, Wohlgemuth SE, Leeuwenburgh C: Sarcopenia of aging: underlying cellular mechanisms and protection by calorie restriction. Biofactors 2009, 35:28-35

59. Li Z, Heber D: Sarcopenic obesity in the elderly and strategies for weight management. Nutr Rev 2012, 70:57-64

60. Muzumdar R, Allison DB, Huffman DM, Ma X, Atzmon G, Einstein FH, Fishman S, Poduval AD, McVei T, Keith SW, Barzilai N: Visceral adipose tissue modulates mammalian longevity. Aging Cell 2008, $7: 438-440$

61. Tremblay F, Krebs M, Dombrowski L, Brehm A, Bernroider E, Roth E, Nowotny P, Waldhäusl W, Marette A, Roden M: Overactivation of S6 kinase 1 as a cause of human insulin resistance during increased amino acid availability. Diabetes 2005, 54:2674-2684

62. Sengupta S, Peterson TR, Laplante M, Oh S, Sabatini DM: mTORC1 controls fasting-induced ketogenesis and its modulation by ageing. Nature 2010, 468:1100-1104

63. Wang C, Maddick M, Miwa S, Jurk D, Czapiewski R, Saretzki G, Langie SA, Godschalk RW, Cameron K, von Zglinicki T: Adult-onset, short-term dietary restriction reduces cell senescence in mice. Aging (Albany NY) 2010, 2:555-566 